\title{
Online Learning Features and Factors in Getting the Blend Right
}

\author{
Conference discussion group paper \\ Paul T. Nleya (Botswana, Chair), Sethunya P. Kgaodi (Botswana. Rapporteur), \\ Letlhogonolo Moaneng (Botswana, Rapporteur), Godfrey S. Kalanke (Botswana), \\ Javier Osorio (Spain), Nicholas B. Mavengere (Finland), Ramaraju Gavarraju \\ (Botswana), Sethunya P. Kgaodi (Botswana), Prince O. Marokane (Botswana), \\ and Selefo Sabone (Botswana)
}

\section{Introduction and Context}

This presentation discusses online learning provision using blended approach in educational settings. Online learning provision in the African setting includes both the traditional e-Learning management systems (e. g. proprietary - blackboard and webCT), and Open Source (i. e. Moodle, KEWL etc.). Online learning can feature at primary, junior and senior secondary as well as tertiary levels. However, within the African context, much emphasis is placed on the tertiary level and the scope of this paper focuses on eLearning provision within the tertiary level where it is believed that necessary resources are available. The paper firstly outlines the features of online learning, secondly outlines several factors that would determine the level and success of online provision in tertiary institutions in Africa; and lastly, discusses challenges and blended learning trends regarding online provision given the several factors in place.

\section{Features of Online Learning Settings}

There exist several features of online learning provision that make it a distinct mode of delivery. Certain prerequisite requirements would enable adequate online provision and the following have been identified as critical attributes of online learning:

- Smart classrooms/Laboratory

- Learning management system (proprietary or open source)

- Course learning tools (synchronous and asynchronous)

- Designing of online course/s

- Geographical barriers are eliminated

- Learning is self-directed

- $\quad$ Learning is self-paced

- On-demand access to learning

- Fostering greater student/instructor contact

- Overall student costs frequently less (tuition, residence, food, child care)

- Learner support 
- Management of course

- Tutor requirements (e. g. uploading of material and editing);

- Moderation of course

- Variety of assessment modes

- Discussions/forums and monitoring

- Contact between students and instructor

- Reciprocity and cooperation among students and staff

- $\quad$ Active learning activities

- $\quad$ Provision of prompt/immediate feedback

- Emphasizes time on task

- Communicates high expectations, and

- Respect for diverse talents and ways of learning

- (Pam Vesely, Lisa Bloom and John Sherlock, 2007)

These above features constitute critical aspects of online delivery and there is need for a basic structure to support online learning provision without which there will be no adequate provision.

\section{Factors Determining Online Learning Provision}

Several general factors tend to determine the level of provision of online learning and the following have been identified:

- $\quad$ Strategic policy Frameworks

- Implementation strategy

- Hacking (changing results, copyright, computer/online literacy)

- Awareness and capability to implement

- Availability of resources

- Technical support

- $\quad$ Age and gender of learners

- Motivation (teacher preparation and students) on how to use online mode

- Previous success on online learning

- Engagement in online activities

- Interaction

- $\quad$ Bad or non-existent advising

- $\quad$ Attitude towards computers ( Phobias)

- Training for capability building

- Infrastructure-(telecommunications, electricity etc.)

- Learning styles of students, and

- $\quad$ Online literacy (Eva Martinez-Caro, 2009)

The identified factors also tend to determine the blending of online learning as there can be no 'one size fits all solution' in online provision. Each institution will have to weigh its capability so as to strike an adequate balance regarding a blending configuration that best fits its needs. Furthermore, some key success factors regarding online learning provision have also been identified as follows: 
Institutional support - addresses technological infrastructure issues, a technology plan, and professional incentives for faculty.

Course Development - this category involves benchmarks for the development of courseware which is produced largely either by individual faculty (or groups of faculty members) on campus, subject experts in organizations and/or commercial enterprises.

Teaching/Learning Process - this category addresses the array of activities related to pedagogy, the art of teaching. Included in this category are process benchmarks involving interactivity, collaboration, and modular learning.

Course Structure - addresses those policies and procedures that support and relate to the teaching/learning process. They include course objectives, availability of library resources, types of material provided to students, response time to students, and student expectations.

Student Support - this category includes the array of student services normally found on a college campus including admissions, financial aid, etc. as well as student training and assistance while using the Internet.

Faculty Support - address activities that assist faculty in teaching online, including policies for faculty transition help as well as continuing assistance throughout the teaching period.

Evaluation Assessment - this category relate to policies and procedures that address how, or if, the institution evaluates Internet-based distance learning. Masoumi D. (n. d.)

\section{Getting the Blending Right}

Creating a blended learning strategy is viewed as an evolutionary process. One needs to explore the capabilities of the team, the organization's infrastructure, and learners' receptiveness to the new learning formats. For many, the first stage in their blended learning program initiative is to supplement their current programs, either traditional classroom or self-paced content libraries, with live eLearning activities (coaching, virtual classrooms or workshops) to extend the learning process and better integrate it with the work environment (Lily Wong and Arthur Tatnall, 2010). There are critical factors that have some bearing on blending configurations that institutions have adopted. These range from staff/students awareness levels to the capacity of the institution in terms of available resources. Some institutions will have acquired higher readiness levels and would therefore aspire to have a blending that is biased in favor of technology while some will have less readiness levels in technology applications and will infuse/integrate less technological applications. Motivation of students and staff regarding the use of technology is also another factor and the time taken by teachers to organize materials online.

Availability of resources has some bearing on online provision. Given that institutions have varying levels of provision of resources. Furthermore, some resources are restricted as laboratories close early while other institutions have open access and unrestricted access to resources and therefore have the potential of integrating more technologies that promote eLearning at an accelerated rate and leading to some rich blending. Technical and pedagogical support is also critical as 
some institutions provide eLearning centres that not only train staff and students, but also assist with instructional design, graphics and other online aspects critical in blended learning. There is need for both technical and pedagogical support in eLearning infusion. This could provide the required capacity building in the eLearning initiatives of institutions of higher learning.

The pedagogical aspect in the implementation of online learning is a critical attribute. Every learning tool has its own modalities and users (students and staff) therefore require training on how to use it in the most effective way. Some areas of specialization (e. g. Math and Science) have the reputation of promoting aspects of online learning while some areas lag behind, and yet technology could be integrated in all areas. Some instructional technologies are commonly used in eLearning while others have not been used significantly for learning purposes despite their being available (e. g. mobile telephone). Both asynchronous and synchronous technologies are used in eLearning together with other convergence technologies depending on how they suit the institution. Copyright/plagiarism and intellectual property issues have become critical when planning online learning delivery. Online courses also require accreditation to make them authentic given the prevalence of fraudulent tendencies practiced by some online institutions.

The critical question for institutions of higher learning to ask is; to what extent can online learning replace classroom teaching (face-to-face)? Blended learning has become the popular mode given that online learning has not yet developed to the extent of replacing face-to-face delivery mode in recent years. Blended learning is viewed as learning that is facilitated by the effective combination of different modes of delivery, models of teaching and styles of learning, and is based on transparent communication amongst all parties involved with a course. The potential of blended learning is almost limitless and represent a naturally evolving process from traditional forms of learning to a personalised and focused development path.

Some professionals merely upload materials onto available online management systems without examining what to put online and how to use it to enhance learning. There is also need for strategic eLearning policies that would guide implementation of effective online practices. One of the most important factors in creating blended learning is to find out where it fits in the broader context of organisational learning and development. The interplay of these factors in institutions of higher learning will determine the appropriate mix of blended learning as there is no one size fits all situation.

\section{Challenges in Online Learning}

Several challenges tend to exist regarding the implementation of eLearning provision at the tertiary level within the African setting. Some of these challenges are as follows:

- Technophobia - attitude towards computers (lecturers and students)

- Computer literacy level for users

- Access to resources

- Cultural changes 
- $\quad$ Skills and expertise for technical support

- Cost of proprietary learning management systems

- $\quad$ Policies issues, (institutional and pedagogical)

- Copyright

- Plagiarism

- Intellectual property

- Data security

- Quality control and assurance issues

- Access to connectivity

- $\quad$ Discomfort with self-directed learning activities, and

- $\quad$ Accreditation of programmes (Stephen Asunka and Hui Soo Chae, 2009)

\section{Conclusion}

The paper has firstly outlined the characteristic features of online learning in the context of tertiary institutions in developing countries with some focus on the African context. Secondly, it discusses several factors that would determine the level and success of online learning provision and lastly, the resulting blended learning trends regarding online provision within tertiary institutions in the African setting. Several challenges have also been associated with the implementation of online learning provision at the tertiary level. It can be concluded that creating a blended learning strategy in online learning provision at the tertiary level in Africa and other developing countries is an evolutionary process, and that there is no 'one size fits all solution'.

\section{References}

Martinez-Caro, E.: An Analysis in Production Management Courses. Business Management Department, Universidad Politećnica de Cartagena, Murcia, Spain (2009) (received November 24, 2008) (accepted February 11, 2009)

Wong, L., Tatnall, A.: Factors Determining the Balance between Online and Face-to-Face

Teaching: An Analysis using Actor-Network Theory. Interdisciplinary Journal of Information, Knowledge, and Management 5 (2010)

Masoumi, D.: Critical factors for effective eLearning, http://asianvu.com/digitallibrary/elearning/Critical_factors_for_effective_e-learning_ by_DMasoumi 5 B1\%5D.pdf (11/08/2010)

Vesely, P., Bloom, L., Sherlock, J.: Key Elements of Building Online Community: Comparing Faculty and Student PerceptionsMERLOT Journal of Online Learning and Teaching 3(3) (September 2007), http://jolt.merlot.org/vol3no3/vesely.htm (retrieved 16/08/10)

Asunka, S., Chae, H.S.: Strategies for Teaching Online Courses within the Sub-Saharan African

Context: An Instructor's Recommendations. MERLOT Journal of Online Learning and Teaching 5(2) (June 2009),

http://jolt.merlot.org/vol5no2/asunka_0609.htm (retrieved 16/08/10) 